\title{
Importance of underwater light field in selecting phytoplankton morphology in a eutrophic reservoir
}

\author{
Ming Su • Wei An • Jianwei Yu • Shenling Pan • \\ Min Yang
}

Received: 13 August 2013/Revised: 14 October 2013/Accepted: 19 October 2013/Published online: 6 November 2013

(C) Springer Science+Business Media Dordrecht 2013

\begin{abstract}
This study attempted to reveal the effect of solar radiation fluctuation on the dynamics of phytoplankton communities expressed as cell morphology in eutrophic water bodies where the impacts of nutrients could be considered as small. Two morphological descriptors were proposed, cellular projected area $\left(\varphi_{\mathrm{p}}\right)$ and flattening index $(f)$, which were able to he cellular light-harvesting potential and energy requirement, respectively. A model was established to describe the effects of natural light availability on selecting phytoplankton assemblages with underwater field and mixing process in the water column considered. Based on the data collected from the eutrophic Yanghe Reservoir, the model was derived as $V=$ $37.92 \lambda \varphi_{\mathrm{p}}\left(R^{2}=0.673, P<0.01\right)$, where $V$ is bio-volume, $\lambda$ is a function of solar elevation angle $(\theta)$ and mixing/euphotic depth ratio $\left(z_{\mathrm{mix}} / z_{\mathrm{eu}}\right)$ in water, and $\varphi_{\mathrm{p}}$. Post-analysis of the model results revealed that species with large $\varphi_{\mathrm{p}}$ and $f$ in general have advantages in
\end{abstract}

Electronic supplementary material The online version of this article (doi:10.1007/s10750-013-1734-z) contains supplementary material, which is available to authorized users.

Handling editor: Luigi Naselli-Flores

M. Su · W. An $(\bowtie) \cdot$ J. Yu $\cdot$ S. Pan $\cdot$ M. Yang

State Key Laboratory of Environmental Aquatic

Chemistry, Research Center for Eco-Environmental

Sciences, Chinese Academy of Sciences, P.O. Box 2871,

Beijing 100085, China

e-mail: anwei@rcees.ac.cn spring and winter when underwater light availability is low; by contrast, those with small $\varphi_{\mathrm{p}}$ and $f$ have advantages in summer. Larger $\varphi_{\mathrm{p}}$ and $f$ mean that the cells could harvest more light energy and consumed less, allowing them to be selected under low light availability; and vice versa. We thus concluded that the underwater light field probably the most important factor in selecting phytoplankton morphology in eutrophic water bodies.

Keywords Phytoplankton succession . Cellular projected area $\cdot$ Flattening index . Phytoplankton morphology · Underwater light field $\cdot z_{\text {mix }} / z_{\text {eu }}$ ratio

\section{Introduction}

Phytoplankton offers a significant morphological diversity (Padisák et al., 2003; Naselli-Flores et al., 2007; Benincàà et al., 2008; Naselli-Flores \& Barone, 2011). The morphological features have been traditionally used just for taxonomic classification of organisms. The ecological value of morphological descriptors in phytoplankton was first recognized to be in relation to uptake of light and nutrients and, as a result of, natural selection and competition by Lewis (1976). Margalef (1978) used life-forms as a determinant of seasonal succession of phytoplankton suggesting that morphological variability has an adaptive value directed toward the best fitting to environmental 
conditions. Reynolds $(1997,2006)$ explained in detail how the diverse ecological strategies adopted by phytoplankton can be related to differences in their morphology. Naselli-Flores \& Barone (2011) summarized the course of scientific research in the last decades and highlighted the most recent findings on the importance of size and shape of phytoplankton in describing the ecological characteristics of the aquatic ecosystems.

The need of exploiting resources under varying environmental conditions is probably one of the most important causes of intra- and inter-specific morphological diversity in phytoplankton (Naselli-Flores, 2000). The extent of entrainment of phytoplankton cells in water motion may be considered as a strategy to explore and exploit resources and the extent of such entrainment largely depends on shape and size, thus having an adaptive value (Padisák et al., 2003). Cuker (1983) and Örnólfsdóttir et al. (2004) revealed that nutrient pulsing was a regulator of phytoplankton abundance and assemblage composition. On the other hand, Elliott et al. (2006) and Kingsolver \& Huey (2008) found that temperature also greatly affected the phytoplankton morphological distribution. O'Farrell et al. (2007) analyzed the effects of underwater light field on selecting phytoplankton assemblages: small unicellular, non-flagellated organisms, thin filaments or small tabular colonies have advantages in light limited environments under nutrient-saturated conditions, whereas flagellated forms and larger organisms prevailed in well-illuminated ones; in addition, NaselliFlores \& Barone (2007) observed significant correlation between the daily availability of underwater light and the dominant morphology in the assemblage of a hypertrophic Mediterranean reservoir. Thus, light availability could be a major force selecting phytoplankton assemblages in eutrophic and hypertrophic environments. Conversely, efficiency in nutrient uptake is more relevant in oligotrophic and mesotrophic ones.

In the last years, morphological and functional analyses of phytoplankton traits have become more and more popular because of the need to find suitable descriptors for the management purposes to monitor the quality of water environments (Reynolds et al., 2002; Weithoff, 2003; Naselli-Flores et al., 2007; Padisák et al., 2009; Kruk et al., 2010; Litchman et al., 2010; Naselli-Flores \& Barone, 2011). The surface/volume $(S / V)$ ratio of a biomass unit influences its uptake of light and nutrients, its release of waste products and heat, and its loss of useful compounds or admission of toxins (Lewis, 1976). This ratio is a qualified parameter in setting an upper limit on lightharvesting potential. On the other hand, several studies have used the departure of cell shapes from spherical form to describe flattening (extension in two planes), and the maximum linear dimension of cell shapes to describe the filament formation (extension in one plane), coupled with $S / V$ ratio (Talling, 1965; Reynolds, 2006; Kirk, 2011). The photosynthetic ability of organisms depends on a wide array of physiological processes, among which the light harvesting is considered as the most important one. However, it is difficult to use these parameters to describe the effective radiated areas (ERA) of phytoplankton cells which could reasonably reflect the cellular lightharvesting potentials in their photosynthetic processes.

Consequently, an index able to directly and effectively describe the photosynthetic characteristics of phytoplankton cells is necessary for better studying the effect of light availability on selecting phytoplankton assemblages. Cellular projected area $\left(\varphi_{\mathrm{p}}\right)$, which is defined as the rectilinear projection of the surface of phytoplankton cells onto a plane normal to the unit vector (Palmer, 2010), was employed to represent ERA in the present study.

This study will be helpful in understanding the importance of underwater light field on selecting phytoplankton morphology in eutrophic water bodies where the impacts of nutrients could be considered irrelevant.

\section{Materials and methods}

\section{Study area}

The Yanghe Reservoir $\left(39^{\circ} 59^{\prime} 45.30^{\prime \prime} \mathrm{N}, \quad 119^{\circ} 12^{\prime}\right.$ $\left.30.20^{\prime \prime} \mathrm{E}\right)$ has a capacity of $3.58 \times 10^{8} \mathrm{~m}^{3}$, a mean depth of $5.7 \mathrm{~m}$, mean water area of $13 \mathrm{~km}^{2}$, and volume of approximately $7.5 \times 10^{7} \mathrm{~m}^{3}$. A bathymetry map was obtained from the interpolated depth data collected from an Acoustic Doppler Current Profiler instrument (ADCP, LAUREL, USA), as shown in Online Resource 1. In the north reservoir zone, the bottom is characterized as flat (slope: $6 \mathrm{~mm} \mathrm{~m}^{-1}$ ) and shallow (mean depth: approximately $2 \mathrm{~m}$ ), whereas the south zone has a maximum depth of $14 \mathrm{~m}$ near the south dam. Two main rivers, the West River and East River, enter the reservoir 
via two large inlets and maintain the reservoir's water storage capacity. The West River was characterized by high pollution loading, contributed by non-treated waste water from numerous starch factories located in Lulong County in the upper river between midSeptember to mid-November of each year (Cai et al., 2006). In contrast, the East River largely comprises ground water with a high nitrogen loading. Approximately $5.83 \times 10^{5} \mathrm{~kg}$ total nitrogen (TN) and $2.8 \times 10^{4} \mathrm{~kg}$ total phosphorus (TP) were loaded from outlet water in 2004, of which $65 \%$ TP loading was from the starch factories, and 50\% TN loading was from the East River (Gao et al., 2010), which caused high concentrations of $\mathrm{TN}$ in the reservoir: $3-7 \mathrm{mg}$ $\mathrm{L}^{-1}$ and TP: $0.04-0.08 \mathrm{mg} \mathrm{L}^{-1}$ (Li et al., 2010); additionally, the mean annual rainfall of Qinhuangdao decreased from 687.9 to $562.0 \mathrm{~mm}$ from the $1950 \mathrm{~s}$ to 2005. Therefore, Yanghe Reservoir started experiencing eutrophication from the 1980s on, with cyanobacteria blooms mainly dominated by Microcystis sp. and/ or Dolichospermum sp. in early summer of each year.

\section{Sampling}

According to the bathymetry and physico-chemical characteristics of the reservoir, six sites were chosen for field sampling. Among them, three were from the north shallow zone: West River (WR), East River (ER), North Center (NC); and three from the deep zone: Reservoir Center (RC), South Dam (SD) and Water Intake (WI, the water intake for drinking water supply), as shown in Fig. 1. Samples were taken approximately monthly between March and October of 2009, however, sampling was not performed during the ice-covered period from November to February. Water temperature, dissolved oxygen (DO), $\mathrm{pH}$, conductivity, salinity, and chlorophyll- $\alpha$ were measured in situ with a multi-parameter probe (YSI-6600, USA); Transparency (SD) was measured with a Secchi disk (diameter: $20 \mathrm{~cm}$, black and white).

Phytoplankton net samples for identification were collected from the surface water $(0.1-0.5 \mathrm{~m}$ below the surface) with a standard net III (76 $\mu \mathrm{m}$ mesh size, simple conical tow net, which is a standard phytoplankton tool used in China), and then preserved in Tissue Culture Flasks $\left(25 \mathrm{~cm}^{2}\right.$, Corning CLS3289, Sigma-Aldrich, USA). At the same time, surface water samples from $0.1-0.5 \mathrm{~m}$ depth were collected and stored in polypropylene bottles, then transported immediately to the laboratory for analysis or pretreatment. Subsamples for nutrients [e.g., phosphate and total dissolved phosphorus (TDP), nitrate and nitrite nitrogen, ammonia and total dissolved nitrogen (TDN)] were analyzed within $48 \mathrm{~h}$ or preserved with acid according to standard analytical techniques (Clescerl et al., 1999). Subsamples for phytoplankton enumeration were preserved initially in volumetric cylinders (100 ml) containing 1\% Lugol's iodine solution.

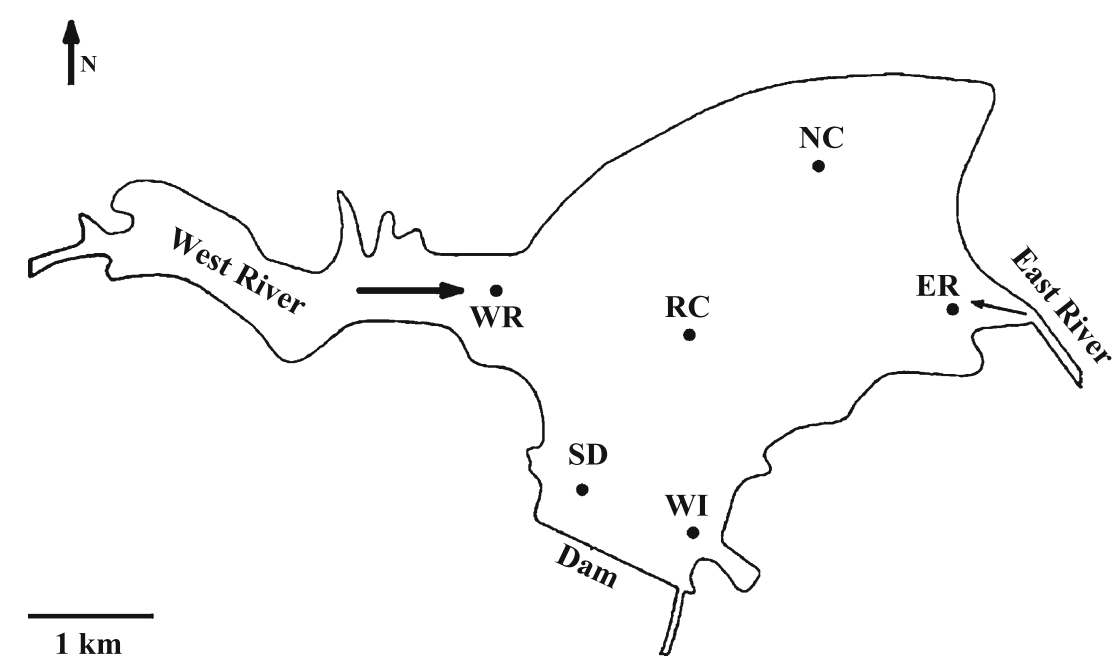

Fig. 1 Sampling sites in the Yanghe Reservoir (WI Water Intake, SD South Dam, WR West River, ER East River, NC North Center, RC Reservoir Center) 
Phytoplankton identification and enumeration

The phytoplankton net samples were initially observed within $24 \mathrm{~h}$ for the purpose of assisting identification, using a light microscope (Olympus BX51) at $200 \times, 400 \times, 600 \times$, or $1,000 \times$ magnification with a Sedgewick Rafter counting chamber. In the present study, species identification was carried out following Prescott (1951), Bellinger (1974), Ling \& Peter (2000), however, species belonging to Chlorococcales were identified by consulting Komárek \& Fott (1983), and the taxonomy of Chroococcales has been updated following Komárek \& Anagnostidis (1998). At the same time, cellular morphological information and image data were also recorded, and used as additional information on biotic characteristics. According to the preliminary results above, the enumeration was subsequently carried out following the method developed by Utermöhl (1958). Preserved subsamples were kept at a standstill for at least $48 \mathrm{~h}$ in settling chambers and then concentrated 10 folds, and ultimately cell counting was performed under a microscope.

Geometric models for phytoplankton cells

Projected area is defined as the rectilinear projection of a surface of any shape onto a plane normal to the unit vector as shown in Eq. (1) (Palmer, 2010),

$\varphi_{\mathrm{p}}=\int_{\varphi} \cos \beta \mathrm{d} \varphi$,

where $\beta$ is the angle between the local tangent plane and the line of sight, and $\varphi$ is the local surface area. The maximum cellular projected area $\left(\varphi_{p^{\prime}}\right)$ is defined as $\left.\max \left(\varphi_{\mathrm{p}}\right)\right|_{\beta}$ (different $\beta$ corresponding to different $\varphi_{\mathrm{p}}$, at least one $\beta$ exists corresponding to the maximum $\varphi_{\mathrm{p}}$ ); for simplicity, the maximum cellular projected area $\left(\varphi_{p^{\prime}}\right)$ is represented by cellular projected area $\left(\varphi_{\mathrm{p}}\right)$ in the following. Based on this, five formulas for $\varphi_{\mathrm{p}}$ of five typical geometric models were then established corresponding to different phytoplankton cell-forms, as shown in Table 1. Subsequently, the $\varphi_{\mathrm{p}}$ and $V$ of phytoplankton cells were obtained (Online Resource 2).

In addition, the arithmetic average of $\varphi_{p}$ and $V$ of each sample were used in the model validation.
Calculation of solar elevation angle

The particles that occur in natural waters have a continuous size distribution, which is roughly hyperbolic according to Kirk (2011). In general, particles in natural water have a diameter greater than $2 \mu \mathrm{m}$, which is large in comparison with the wavelengths of visible light. Thus in most cases, the scattering is in the forward direction within small angles of the beam axis. The visible light ray direction was considered to be from surface to bottom in this study.

On the other hand, the solar elevation angle, defined as the angle between the direction of the geometric center of the sun's apparent disk and the (idealized) horizon (Woolf, 1968), is a function of the latitude, altitude of the location, the time of day, and the date in a year. The daily maximum solar elevation angle $(\theta$, 12:00 a.m., local time) was used to present the daily characteristics of the solar radiation. The calculations were performed with the solar position algorithm of Reda \& Andreas (2004).

Calculation of mixing/euphotic depth $\left(z_{\mathrm{mix}} / z_{\mathrm{eu}}\right)$ ratio

The potential water density was estimated from the profiles of water temperature measured between 9:00 a.m. and 11:00 a.m. on the sampling day. In this study, the mixing depth $\left(z_{\text {mix }}\right)$ was defined as the depth at which the potential density in the upper layer changes by $0.03 \mathrm{~kg} \mathrm{~m}^{-3}$ relative to the surface density. On the other hand, the euphotic depth $\left(z_{\mathrm{eu}}\right)$ is estimated as the depth whereby light energy was reduced to $1 \%$ of the intensity immediately below the water surface (Oliver et al., 1999). To be noted that, the perception of $z_{\mathrm{eu}}$ will differ for algal species, which partly depends on the cells' pigment equipment; thus such a difference among different species should be considered in the future studies.

\section{Model construction}

The main factors affecting phytoplankton morphological include nutrients, water temperature, light availability, etc. (Naselli-Flores \& Barone, 2003, 2005; Elliott et al., 2006; Kingsolver \& Huey, 2008). Water temperature could be integrated into light availability since it is highly related to solar radiation. So we assumed that the most efficient light harvesters are the ones that do best in the competition in a eutrophic 
Table 1 The formulas of maximum cellular projected area $\left(\varphi_{\mathrm{p}}\right)$ for 5 typical geometric models

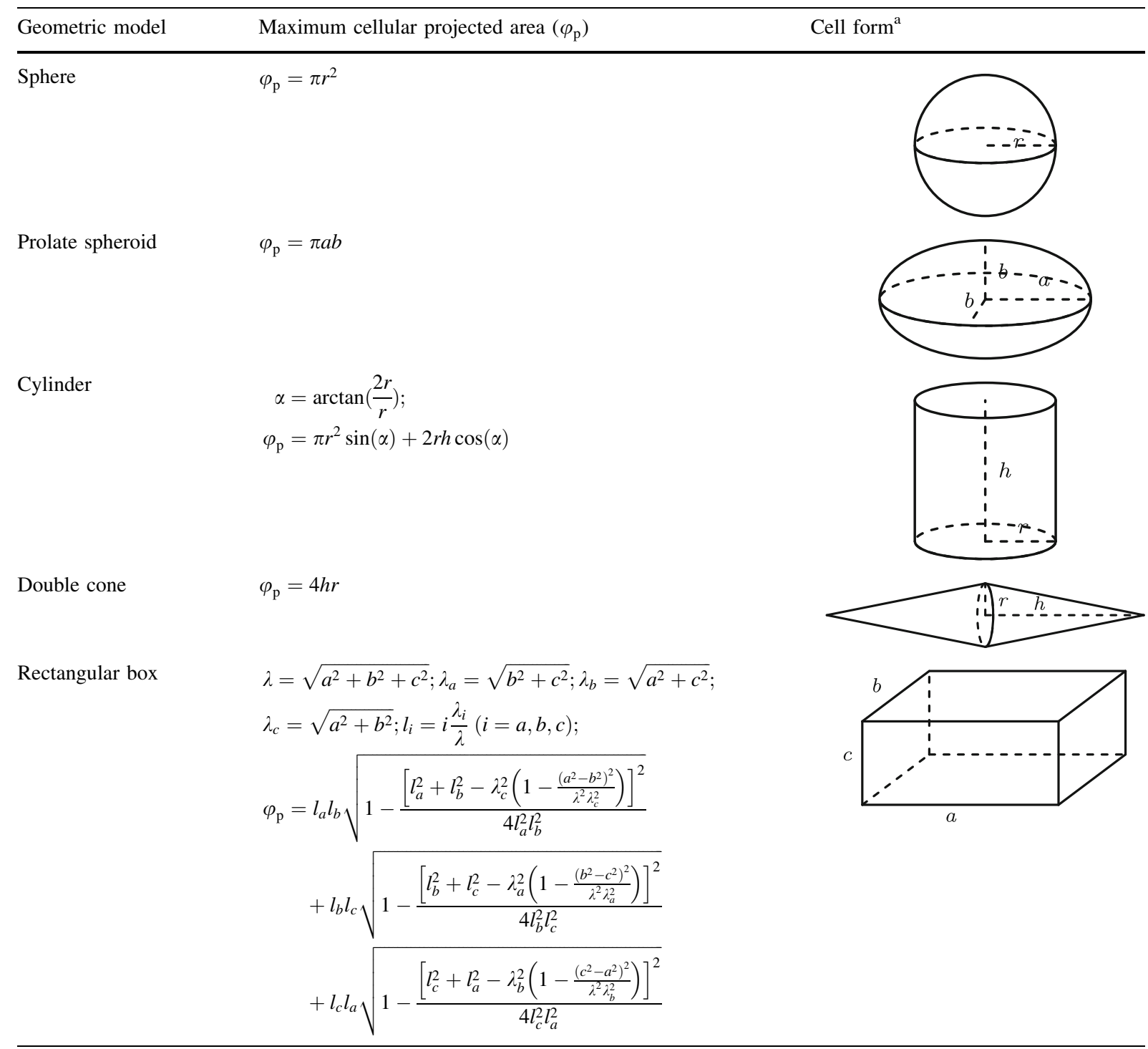

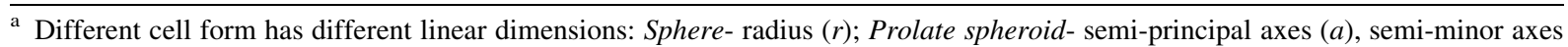
$(b, a>b)$; Cylinder- radius $(r)$, height $(h)$; Double cone- radius $(r)$, height $(h)$; Rectangular box- length $(a)$, width $(b)$, height $(c)$

water body where the effects of nutrients are small. This study attempted to describe the importance of underwater light field on selecting phytoplankton morphology. To maintain the simplicity of the proposed model, Yanghe Reservoir, a eutrophic water body, was chosen for the study, which made it possible to focus mainly on the morphological adaptivity of phytoplankton to the light availability. So the conditions of this reservoir were assumed to favor the cells with adaptive lightharvesting potential over those with better nutrient exploring potential (Bruggeman \& Kooijman, 2007). It should be noted that, however, the impacts of nutrients should be considered in the future to improve the applicability of the model. Another limitation of this study was that only cell shape (the colony organisms were considered as single cells) was included, while other factors including pigment content, composition, etc., may also be important to light availability (Reynolds, 2006).

As the most essential physiological process for phytoplankton, photosynthesis converts light energy to 
chemical energy and conserves it in the bonds of sugar (Smestad, 1998). The underwater light field and cellular light-harvesting potential are two of the most important factors affecting photosynthesis of phytoplankton. The former is mainly determined by solar radiation, water transparency, and in situ depth, while the latter is determined by $\varphi_{\mathrm{p}}$ of the cells. Under a low underwater light field condition, the cells with a high $\varphi_{\mathrm{p}}$ have the advantage. On the other hand, vertical positions of phytoplankton cells and colonies are strongly affected by their degree of entrainment in the water motion.

The photosynthesis rate depends significantly upon the intercepted radiation (Taguchi, 1976; Reynolds, 2006); on the other hand, large cells have the capacity of capturing more light energy due to the large cell size or precisely, $\varphi_{\mathrm{p}}$. We assume a fixed photosynthetic efficiency of phytoplankton under the same solar radiation, implying that the light energy absorption $\left(\Psi_{1}\right)$ is therefore mainly dependent on $\varphi_{\mathrm{p}}$, in situ light intensity $(I)$, as well as sunlit time $(T, T \leq 24 h)$ on a day-scale, as shown in Eq. (2). (In essence, the photosynthetic efficiency was omitted in the equation.)

$\Psi_{1}=\int_{0}^{T} I \varphi_{\mathrm{p}} \mathrm{d} t$

Among these factors, in situ light field was determined by water transparency and solar radiation, which can be expressed by the Beer-Lambert law, as shown in Eq. (3a); on the other hand, the vertical position of phytoplankton depends on vertical mixing process, the degree of entrainment in the water motion as well as regulation by buoyancy. However, the effects of entrainment on different cells were considered to be invariable, and the regulation by buoyancy was ignored. Since the mixing process is very fast compared to the day-scale, the cells spent their time equally in different vertical positions, so the cell migration model thus can be regarded as a uniform vertical motion. Based on this, $\Psi_{1}$ can be presented as Eq. (3c),

$I=I_{0} \exp (-k z)$

$z=\frac{z_{\text {mix }}}{T} t$

$\Psi_{1}=\int_{0}^{T} I_{0} \exp \left(-k t \frac{z_{\text {mix }}}{T}\right) \varphi_{\mathrm{p}} \mathrm{d} t$, where $I_{0}$ denotes the local light intensity near the surface, and $k$ denotes the extinction coefficient. According to the definition of euphotic depth $\left(z_{\mathrm{eu}}\right)$, the light intensity at depth $z_{\mathrm{eu}}$ is $1 \%$ of that in the surface layer, and the extinction coefficient $k$ thus can be determined, as shown in Eq. (4a), (4b).

$1 \% I_{0}=I_{0} \exp \left(-k z_{\text {eu }}\right)$

$k=-\frac{\ln (0.01)}{z_{\mathrm{eu}}}$

With regard to illuminated time $\left(T_{\mathrm{v}}\right)$ of the phytoplankton cells, two conditions are considered here, which are based on different behaviors of phytoplankton under different $z_{\text {mix }} / z_{\text {eu }}$ ratios. Condition one: $z_{\text {mix }}>z_{\text {eu. }}$. The main characteristic of this case is that the phytoplankton cells spend a proportion of their daylight period in the dark. According to the previous assumption, the proportion essentially is the euphotic/ mixing depth $\left(z_{\mathrm{eu}} / z_{\mathrm{mix}}\right)$ ratio. The ultimate form of the equation (5c) was derived from Eq. (5a) and (5b).

$T_{\mathrm{v}}=\frac{z_{\mathrm{eu}}}{z_{\mathrm{mix}}} T$

$\Psi_{1}=\int_{0}^{\frac{z_{\text {eu }}}{z_{\text {mix }}}} I_{0} \exp \left(-k t \frac{z_{\text {mix }}}{T}\right) \varphi_{\mathrm{p}} \mathrm{d} t$

$\Psi_{1}=2.150 I_{0} T \varphi_{\mathrm{p}} \frac{z_{\mathrm{eu}}}{z_{\mathrm{mix}}}$

Condition two: $z_{\mathrm{mix}} \leq z_{\mathrm{eu}}$. By contrast, the cells are constantly illuminated during the daytime. Similarly, the ultimate form is given as Eq. (6c).

$T_{\mathrm{v}}=T$

$\Psi_{1}=\int_{0}^{T} I_{0} \exp \left(-k t \frac{z_{\text {mix }}}{T}\right) \varphi_{\mathrm{p}} \mathrm{d} t$

$\Psi_{1}=0.2171 I_{0} T \varphi_{\mathrm{p}} \frac{z_{\mathrm{eu}}}{z_{\text {mix }}}\left(1-\exp \left(\frac{-4.6052 z_{\text {mix }}}{z_{\mathrm{eu}}}\right)\right)$

Indeed, the quantity $I_{0} T$ is daily total solar radiation intensity, which is strictly seasonal in variation and can be reasonably reflected by $\sin \theta$. Let $\rho=$ $z_{\text {mix }} / z_{\mathrm{eu}}, I_{0} T=\beta \sin \theta$, the two equations can be integrated to one as shown in Eq. (7).

$\Psi_{1}=\beta \lambda \varphi_{\mathrm{p}}$ 
where

$\lambda= \begin{cases}2.150 \rho^{-1} \sin \theta & \rho>1 \\ 0.2171 \rho^{-1}(1-\exp (-4.605 \rho)) \sin \theta & \rho \leq 1\end{cases}$

Photosynthesis converts solar energy into the chemical energy of sugar and other organic compounds, which then drives all physiological processes in phytoplankton as well as supports corresponding biomass. By assuming a fixed fraction of energy requirement per unit biomass in phytoplankton cells ( $V=K \Psi_{1}$ ), the model can be ultimately expressed as Eq. (9),

$V=k \lambda \varphi_{\mathrm{p}}$

where $k=K \beta$. In essence, the model has definite geometric implication to some extent if an algal cell is regarded as an oblate spheroid ( $a=b>c, a, b$ : semiprincipal axes, $c$ : semi-minor axes). In this geometric model, $V$ corresponds to volume, and $\varphi_{\mathrm{p}}$ corresponds to the area of the quatorial plane $\left(\varphi_{\mathrm{p}}=\pi a b\right)$. According to the volume formula of an oblate spheroid $\left(V=\frac{4}{3} \pi a b c\right), k \lambda=\frac{4}{3} c$ can be easily deduced, in other words, $1.5 k \lambda$ can be considered as the equivalent cell height corresponding to the minor axis length of the oblate spheroid $(2 c)$.

The flattening index $(f)$ of the oblate spheroid as defined in Eq. (10a), was used to describe the cell morphology. The cells with a small $f$ value are close to a spherical form, such as Microcystis sp.; in contrast, the cells with a large $f$ value are close to a pie-like form, such as Pediastrum sp..

$$
\begin{aligned}
& f=\frac{a-c}{a} \\
& a=\sqrt{\frac{\varphi_{\mathrm{p}}}{\pi}} \\
& c=0.75 k \lambda
\end{aligned}
$$

\section{Results}

Thermal conditions and nutrients

Significant temporally and spatially variations in mixing depth $\left(z_{\text {mix }}\right)$ were detected during the study period (Online Resource 3 ). The mixing process in WI (see Fig. 1) was stronger than at other locations owing to the rapid outflow for water intake; however, $z_{\text {mix }}$ was relatively low in the north zone even through two main streams flowed into this area. On the other hand, the reservoir was strictly thermally stratified and the water mass at the bottom became deoxygenated from late June to mid-September, while the surface water was well oxygenated. The minimum $z_{\text {mix }}$ of approximately $0.5 \mathrm{~m}$ was observed from late July to August. At that time, the maximum temperature of $27^{\circ} \mathrm{C}$ was observed in the surface layer, while it was $7^{\circ} \mathrm{C}$ lower in the bottom layer. With regard to transparency, the minimum SD of lower than $0.5 \mathrm{~m}$ and the maximum of approximately $2 \mathrm{~m}$ were observed in August and March, respectively. In addition, fluctuations of $\mathrm{pH}$ and conductivity mirrored those of the photosynthetic activity: $\mathrm{pH}$ showed minima (7.5) in March, and maxima (9.4) in the summer period, whereas the opposite happened for conductivity, due to the summer precipitation of carbonate, caused by algal $\mathrm{CO}_{2}$ depletion $\left(\max 320, \min 260 \mu \mathrm{S} \mathrm{cm}^{-1}\right)$.

The seasonal variations of the main algal nutrients in the central reservoir (dissolved phosphorus, nitrate nitrogen, ammonia nitrogen, and nitrite nitrogen) were the opposite with respect to temperature, with maxima in March and minima between July and September. The range of the measured concentrations was $10-180 \mu \mathrm{g} \mathrm{l}^{-1}$ for TDP, $1.17-5.79 \mathrm{mg} \mathrm{l}^{-1}$ for TDN, $0.97-4.94 \mathrm{mg} \mathrm{l}^{-1}$ for nitrate nitrogen and $0.072-$ $0.640 \mathrm{mg}^{-1}$ for ammonia nitrogen. Nitrite nitrogen was usually low: slightly higher values were occasionally recorded in summer and autumn (around $80 \mu \mathrm{g} \mathrm{l}^{-1}$ ), whereas in spring the concentration dropped to $20 \mu \mathrm{g}^{-1}$ or even less. In general, the nutrient concentrations increased compared with those reported in 2007 ( $\mathrm{Li}$ et al., 2010).

Phytoplankton dynamics

Eighty-two species/genera belonging to seven algal divisions-Chlorophyta (40\%, species abundance), Cyanophyta (24\%), Bacillariophyta (21\%), Chrysophyta (4\%), Pyrrophyta (4\%), Cryptophyta (2\%), and Euglenophyta $(2 \%)$-were identified in the present study (Online Resource 4). In spring the dominant species were Peridinium sp., Closterium kuetzingii, Melosira varians, and Fragilaria sp. From June to September, the phytoplankton assemblage was characterized by the overwhelming dominance of Microcystis aeruginosa (peak density: 479,000 cells $\mathrm{ml}^{-1}$ 
and Microcystis wesenbergii (peak density: 149,600 cells $\mathrm{ml}^{-1}$ ). In late autumn, however, Microcystis sp. showed a sharp drop to 1,500 cells $\mathrm{ml}^{-1}$.

\section{Phytoplankton cellular morphology}

The size of phytoplankton covered more than six orders of magnitude ranging from picoplankton $\left(<1 \mu \mathrm{m}^{3}\right)$ to large dinoflagellates $\left(>50,000 \mu \mathrm{m}^{3}\right)$, and the colonial organism like Microcystis (several thousands of cells, $<1,000 \mu \mathrm{m}^{3}$ ) were considered as small size cells because each cell grows independently for most physiological processes.

Among the phytoplankton species observed in the present study, Raphidiopsis sp. and Closterium kuetzingii exhibited the minimum $\left(5.59 \mu^{2}\right)$ and maximum $\left(5,518 \mu \mathrm{m}^{2}\right) \varphi_{\mathrm{p}}$, respectively. Nevertheless, species with a $\varphi_{\mathrm{p}}$ value greater than $500 \mu \mathrm{m}^{2}$ were rarely exhibited. As shown in Fig. 2, the distribution pattern showed great dissimilarities in different seasons. In March, the $\varphi_{\mathrm{p}}$ was relatively uniformly distributed in the range of $0-500 \mu \mathrm{m}^{2}$, consisting of five peaks $\left(\phi_{1}-\phi_{5}\right)$ at $19.5,58.5,129,168$, and $254 \mu^{2}$ cell $^{-1}$. In April, three peaks $\left(\phi_{1}, \phi_{2}, \phi_{3}\right)$ were observed, among which, the first peak decreased to $18.0 \mu \mathrm{m}^{2}$ cell $^{-1}$ compared to that in March. In contrast, the $\varphi_{\mathrm{p}}$ was mainly distributed around the first peak $\phi_{1}$ during June to July, showing a significant difference from that in other seasons $(P<0.01)$ according to the Mann-Whitney Test (Online Resource 5). From August on, the first peak $\varphi_{1}$ began to increase, and three peaks appeared in October.

\section{Phytoplankton assemblage characteristics}

In the present study, temporal heterogeneity was established through a noisy seasonally fluctuating light intensity; on the other hand, spatial heterogeneity was established by considering the physical characteristics of different sampling sites. As shown in Table 2, the spatially varying physical conditions did not affect the biodiversity, while the time-varying light intensity showed a significant influence: the minimum diversity was observed in July when a cyanobacterial bloom dominated by Microcystis sp. occurred; while in winter the diversity greatly increased till the maximum diversity was achieved in the next spring.
Model validation

Fifty-three samples collected from the Yanghe Reservoir were used to validate the proposed model of Eq. (9). Among the samples, it was found that the $z_{\text {mix }} \leq z_{\text {eu }}$ condition mainly occurred in July and August, while the $z_{\text {mix }}>z_{\text {eu }}$ condition occurred in other seasons with the highest values $\left(z_{\text {mix }} / z_{\text {eu }}>3\right)$ mainly observed in the deep zone (RC, SD, WI) in October, as shown in Table 3. The variations of $z_{\mathrm{mix}} / z_{\mathrm{eu}}$ ratio were significantly different $(P<0.05)$ between the shallow zone (NC, ER, WR) and the deep zone. $\lambda$ was then calculated according to Eq. (8).

The data of $\lambda \varphi_{\mathrm{p}}$ versus $V$ was plotted in Fig. 3. All of the data, with one exception, were well explained by the proposed model Eq. (9), and the result was given in Eq. (11). Long-term ice-covered condition during winter could be the possible reason for the abnormal data (March, SD).

$V=37.92 \lambda \varphi_{\mathrm{p}} \quad\left(R^{2}=0.673, P<0.01\right)$

\section{Discussion}

Post-analysis

$f$ and $\varphi_{\mathrm{p}}$ are two essential morphological descriptors of phytoplankton for the study of cellular light-harvesting potentials. $\varphi_{\mathrm{p}}$ reflects ERA, implying lightharvesting potential, while $f$ reflects the $\varphi_{\mathrm{p}} / V$ ratio, implying the energy requirement. Compared to surface area (SA), CPA showed slightly higher correlation coefficients with light availability (no significant difference, Online Resource 6); however, the sensitivity of CPA is higher than that of SA, which could increase the accuracy of results (the difference of CPA between a large pie-like cell and a small sphere-like cell is higher that of SA); in the present study, the range of CPA is around 27-220, with the data scale folds of 8.15 (220/ 27), which is higher that of SA (6.5); in addition, the physical significance of CPA is obviously and it could directly reflect the cellular light-harvesting potential; thus the CPA is superior to SA for interpreting the cellular light-harvesting potential.CPA could reflect the information of $X \times Y$ plane, and flattening index (f) could reflect the information of $Z$-axis as well the cell volume; therefor the combination of the two 


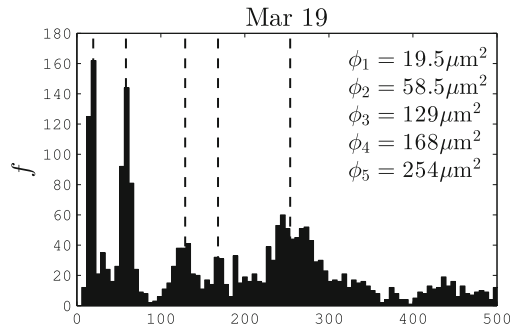

$\varphi_{p}\left[\mu m^{2}\right]$
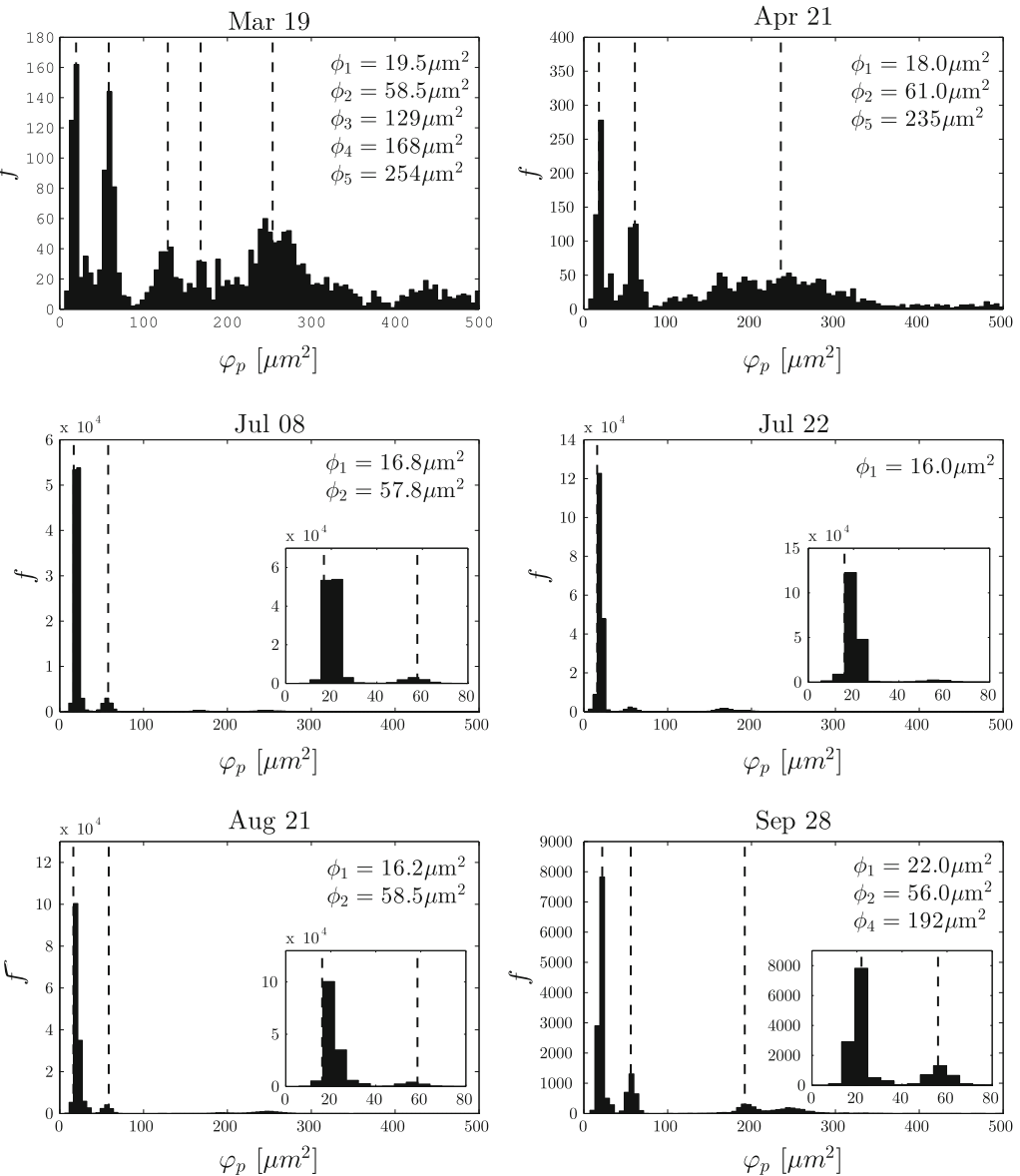

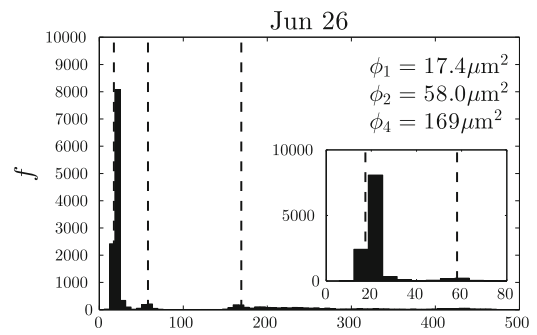

$\varphi_{p}\left[\mu m^{2}\right]$
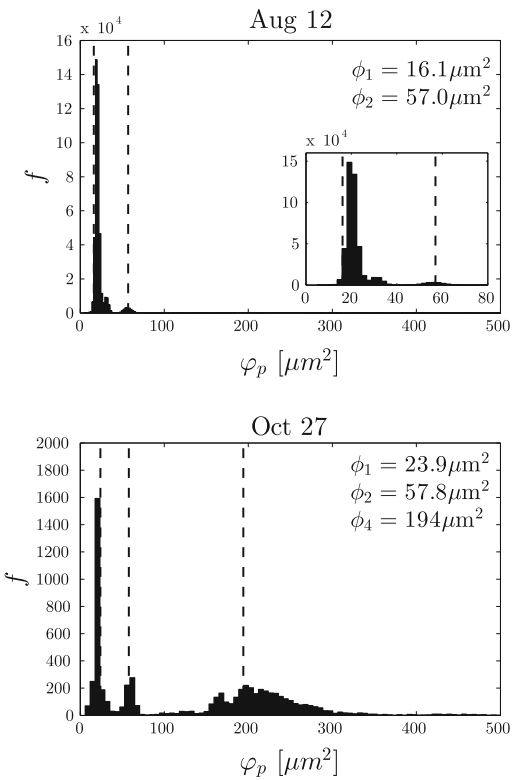

Fig. 2 The cellular projected area $\left(\varphi_{\mathrm{p}}\right)$ distribution of phytoplankton assemblage in Yanghe Reservoir in 2009 (the range of $\varphi_{\mathrm{p}}>500 \mu \mathrm{m}^{2}$ was not shown, $\phi_{1}-\phi_{5}$ are the $\varphi_{\mathrm{p}}$ of the distribution peaks)

Table 2 Diversity values (Shannon index) computed in the Yanghe Reservoir during the studied period

\begin{tabular}{llllllllll}
\hline Date: & Mar 19 & Apr 21 & Jun 26 & Jul 08 & Jul 22 & Aug 12 & Aug 21 & Sep 28 & Oct 27 \\
\hline NC & 0.87 & 0.87 & 0.34 & 0.15 & 0.39 & 0.37 & 0.50 & 0.64 & 0.76 \\
ER & 0.88 & 0.86 & 0.36 & 0.14 & 0.34 & 0.41 & 0.29 & 0.64 & 0.63 \\
WR & 0.89 & 0.83 & 0.40 & 0.10 & 0.31 & 0.41 & 0.35 & 0.61 & 0.78 \\
RC & 0.81 & 0.82 & 0.42 & 0.14 & 0.19 & 0.35 & 0.33 & 0.42 & 0.73 \\
SD & 0.90 & 0.87 & 0.37 & 0.16 & ND $^{\mathrm{a}}$ & 0.26 & 0.26 & 0.58 & 0.74 \\
WI & 0.92 & 0.90 & 0.34 & 0.28 & 0.42 & 0.27 & 0.33 & 0.59 & 0.78 \\
\hline
\end{tabular}

a Sampling was not performed

descriptors could express the cellular light-harvesting potential and enery consumption level; $\mathrm{M}$ S/V can reflect the information of $X \times Y$ plane as well as the cell volume, however, it is difficult to express the information of $Z$-axis; in addition, the information given by $\mathrm{M} \mathrm{S} / \mathrm{V}$ is very sensitive to the cellular maximum linear dimension. M S/V ratio (bottom-left) showed higher variance than $f$ (bottom-right), which is mainly contributed by the maximum linear dimension of the cell (the M S/V of rhomboid cell is very different from the pie-like cell with equivalent cell volume, Online Resource 6). Thus, $f$ is the best 
Table 3 The mixing/euphotic depth $\left(z_{\mathrm{mix}} / z_{\mathrm{eu}}\right)$ ratio in the Yanghe Reservoir

\begin{tabular}{lllllllllll}
\hline Date: & Mar 19 & Apr 21 & Jun 26 & Jul 08 & Jul 22 & Aug 12 & Aug 21 & Sep 28 & Oct 27 & Var. \\
\hline NC & $1.00^{\mathrm{a}}$ & $1.00^{\mathrm{a}}$ & 0.83 & 0.98 & 0.41 & 0.70 & 1.10 & 0.76 & 0.98 & 0.046 \\
ER & 1.16 & 1.50 & 0.58 & 0.93 & 0.78 & 0.81 & 0.96 & 0.89 & 1.23 & 0.076 \\
WR & $1.00^{\mathrm{a}}$ & $1.00^{\mathrm{a}}$ & 0.39 & 0.90 & 0.63 & 0.63 & 0.76 & 1.14 & 1.35 & 0.088 \\
RC & 1.80 & 2.17 & 1.39 & 0.54 & 0.14 & 0.23 & 0.56 & 0.85 & 3.60 & 1.264 \\
SD & 0.48 & 1.45 & 1.13 & 0.32 & 0.28 & 0.52 & 1.55 & 1.88 & 3.13 & 0.873 \\
WI & 2.16 & 1.52 & 1.56 & 0.26 & 1.14 & 0.80 & 0.83 & 4.17 & 3.64 & 1.752 \\
\hline
\end{tabular}

a The water column was well mixed $\left(z_{\operatorname{mix}}=z_{\max }\right)$, and well illuminated $\left(z_{\mathrm{eu}}=z_{\max }\right)$

parameter to describe the light-related process for algal cells couple with CPA. According to the model result, the transformed flattening index $\left(f^{\prime}=e^{\mathrm{f}} / e\right)$ was used to avoid appearance of negative values for $f$. It is clear that high $f^{\prime}$ values occurred in winter and spring, while low $f^{\prime}$ values were observed in July and August, as shown in Fig. 4 (top). The phytoplankton morphological succession showed significant seasonality as shown in Fig. 4 (bottom). From spring to summer, the dominant cells changed from large pie-like cells (large flattening index and cellular projected area) to small sphere-like cells (small flattening index and cellular projected area); from autumn to winter, the dominant cells changed back to large pie-like cells along with a different path line as indicated by the arrows in Fig. 4 (bottom).

The behavior of the phytoplankton assemblage can be viewed as a response to the varying environmental conditions. In March and April, the phytoplankton experienced low light levels, due to low solar radiation as well as strong mixing (Bruggeman \& Kooijman, 2007). In this period, light limited phytoplankton growth to such an extent that biota levels were nearly negligible in spite of the presence of abundant nutrients. The few individuals (Fig. 5) with a large $\varphi_{\mathrm{p}}$ and $f$ value do persist due to the high lightharvesting potential and low energy requirement; consequently, the reservoir was dominated by large pie-like cells or equivalents including Peridinium sp., Closterium kuetzingii, Aulacoseira granulata, and Fragilaria sp. (Online Resource 4). With the increase in light intensity along with water temperature, the reservoir started to develop thermal stratification and the first phytoplankton bloom appeared in June. Then the cells with relatively small $\varphi_{\mathrm{p}}$ and large $f$ values like Navicula sp., Perdinium sp., Ceratium hirundinella, etc., mainly contributed to the biomass. Shortly after the onset of the bloom when light was amply available, the cells with a high $S / V$ ratio, such as Microcystis aeruginosa and Microcystis wesenbergii dominated the reservoir because of their high nutrient exploring potential, while large cells were rarely observed in the present study. The depleted environment was then compensated by vertical mixing as the year progressed (Boehrer \& Schultze, 2008); simultaneously, solar radiation decreased in the following few months. Under this situation, the environment began to favor species with a high light-harvesting potential. Consequently, species with large $f$ and $\varphi_{\mathrm{p}}$ including Synedra sp. and Cyclotella sp. dominated the reservoir in this period. In general, an annual cycling of phytoplankton morphological succession could be illustrated by $\varphi_{\mathrm{p}}$ and $f$ (Fig. 4 bottom). The phytoplankton succession is well explained by the model, although it was established on the premise of light-limiting conditions. Nevertheless, other factors affecting behaviors of the

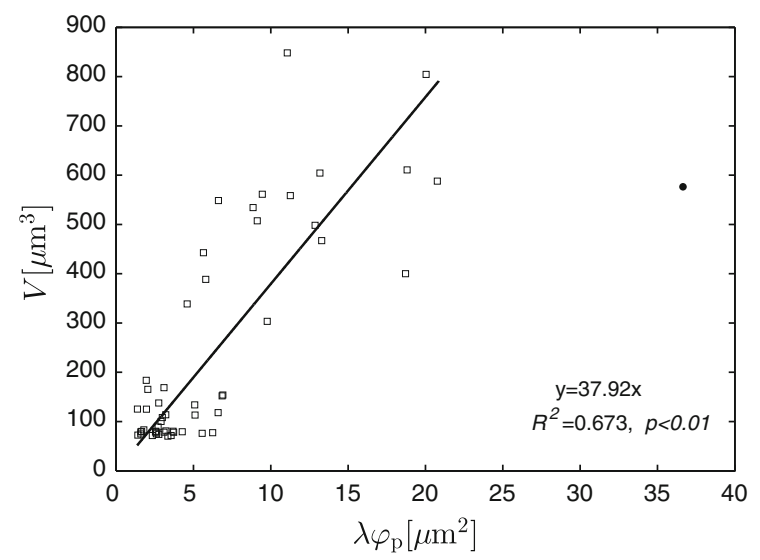

Fig. 3 The model simulation: the morphological response to environmental variables including solar radiation and mixing process in the water column 

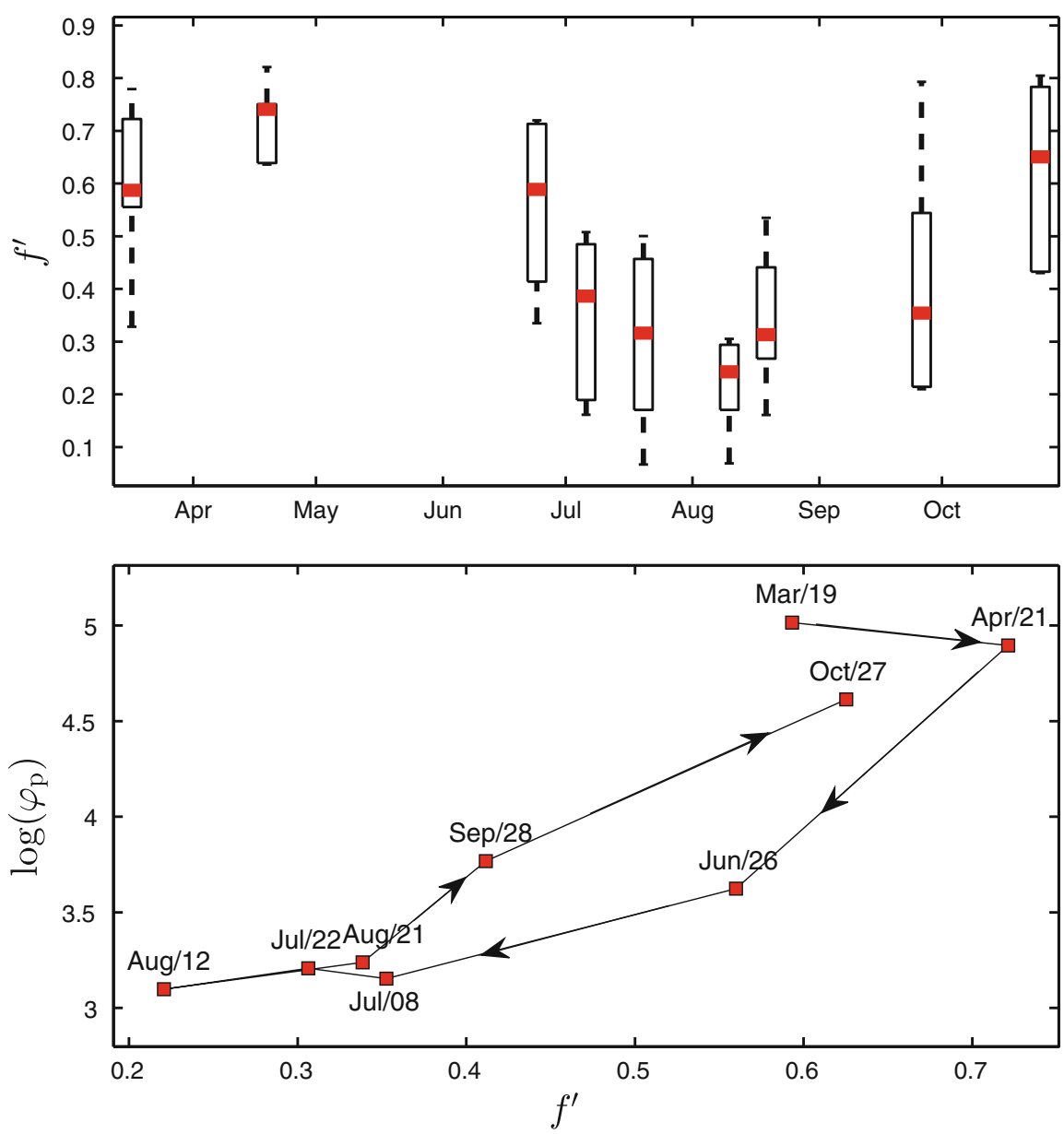

Fig. 4 The transferred flattening index $\left(f^{\prime}=e^{\mathrm{f}} / e\right)$ dynamics of the phytoplankton assemblage in the Yanghe Reservoir (top); phytoplankton morphological succession is well illustrated by the two indices of $\log \left(\varphi_{\mathrm{p}}\right)$ and $f^{\prime}$ (bottom)

phytoplankton assemblage is necessary in future studies.

Most environmental factors are directly or indirectly governed by the seasonal cycle of solar radiation. So light availability tended to significantly affect phytoplankton morphological succession in eutrophic water environments like Yanghe Reservoir. As shown in Fig. 5, the environment appeared to favor the species with small sphere-like form in the periods with sufficient light, and the species with large pie-like form or equivalent in light-limiting periods.

By applying the two descriptors to $\mathrm{C}-\mathrm{S}-\mathrm{R}$ strategies (Grime, 1988; Reynolds, 2006), the cells with high $f$ and medium $\varphi_{\mathrm{p}} / V$ growing well at low temperature and light availability could be considered as C-strategist, implying invasive and ecological pioneers. Low $f$ cells implying large unicells are considered as S-strategist; the cells with high $f$ and $\varphi_{\mathrm{p}}$ are good at light harvesting and maintaining growth at low average light levels and being tolerant to wellmixed, poorly insolated environments could be considered to be R-strategist (Elliott et al., 1999).

Model perspective

Nevertheless, the model ignored and/or simplified some processes at present: the effects of nutrients on selecting phytoplankton assemblages, the effects of wind on the mixing process, the vertical movement of cells, formation of colonies by some species, direct selection by predators, etc. Thus, more efforts are required to improve the model in order to apply it to other water bodies under different environmental conditions. 


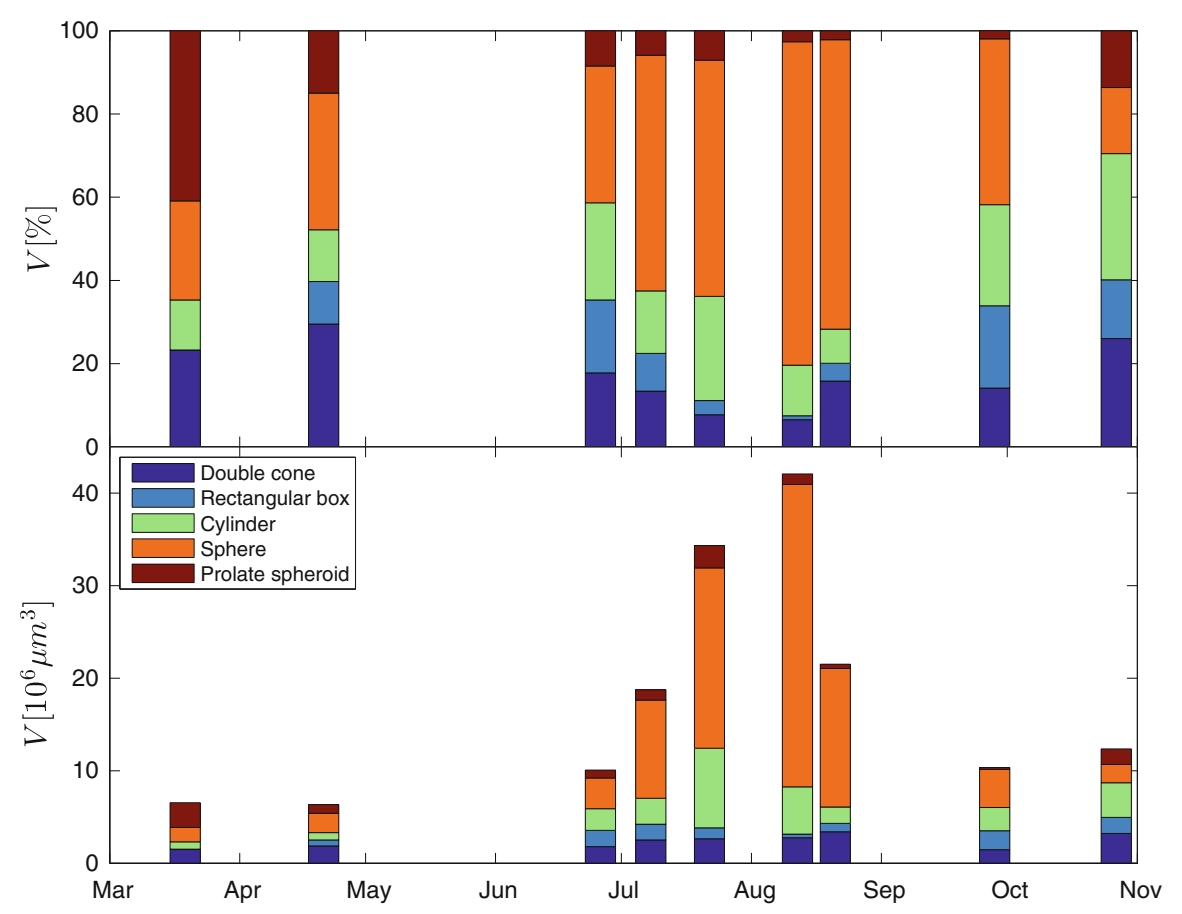

Fig. 5 Phytoplankton succession expressed as different cell-form distribution in Yanghe Reservoir, biomass percentage distribution (top); absolute biomass distribution (bottom)

\section{Conclusion}

Two morphological descriptors, cellular projected area $\left(\varphi_{\mathrm{p}}\right)$ and flattening index $(f)$, were proposed for phytoplankton to express the cellular light-harvesting potential and energy requirement level, respectively. A model was established to describe the importance of underwater light field in selecting phytoplankton morphology in eutrophic water bodies, and was validated using the investigation data acquired from Yanghe Reservoir. The result revealed significant seasonal variation in the distribution of phytoplankton assemblages: the species with large $\varphi_{\mathrm{p}}$ and $f$ were abundant in spring and winter; in contrast those with small $\varphi_{\mathrm{p}}$ and $f$ had the advantages in summer. Thus, the underwater light field may probably be the most important factor in selecting phytoplankton morphology in eutrophic water bodies. Nevertheless, the model ignored and/or simplified some processes, and improvement is required in order to apply it to other water bodies under different environmental conditions.

Acknowledgments We greatly thank Peter Baker who assisted us for the algal taxonomy and identification; we also thank Per Johan Færøvig to give us very good suggestions and comments which improved the work a lot. Finally, we are greatly indebted the editor and reviewers' comments and suggestions on the manuscript. This work was financially supported by the National Natural Science Foundation of China (50938007, 51221892).

\section{References}

Bellinger, E. G., 1974. A key to the identification of the more common algae found in British freshwaters. Water Treatment and Examination 23: 76-131.

Benincà, E., J. Huisman, R. Heerkloss, K. D. Jöhnk, P. Branco, E. H. Van Nes, M. Scheffer, \& S. P. Ellner, 2008. Chaos in a long-term experiment with a plankton community. Nature 451(7180): 822-825.

Boehrer, B., \& M. Schultze, 2008. Stratification of lakes. Reviews of Geophysics 46(2): RG2005.

Bruggeman, J., \& S. A. L. M. Kooijman, 2007. A biodiversityinspired approach to aquatic ecosystem modeling. Limnology and Oceanography 52(4): 1533-1544.

Cai, J., W. Li, N. Liu, Y. Sun, \& J. Yang, 2006. Investigation and analysis of pollution sources in Yanghe Reservoir. China Rural Water and Hydropower (in Chinese) 9: 51-56.

Clescerl, L. S., A. E. Greenberg, \& A. D. Eaton, 1999. Standard Methods for Examination of Water Wastewater, 20th edn. American Public Health Association, American Water Works Association, Water Environment Federation, Washington. 
Cuker, B. E., 1983. Grazing and nutrient interactions in controlling the activity and composition of the epilithic algal community of an arctic lake. Limnology and Oceanography 28(1): 133-141.

Elliott, J. A., C. S. Reynolds, A. E. Irish, \& P. Tett, 1999. Exploring the potential of the PROTECH model to investigate phytoplankton community theory. Hydrobiologia 414: 37-43.

Elliott, J. A., I. D. Jones, \& S. J. Thackeray, 2006. Testing the sensitivity of phytoplankton communities to changes in water temperature and nutrient load, in a temperate lake. Hydrobiologia 559: 401-411.

Gao, T., X. Qian, Z. Chu, S. Wang, J. Wu, X. Chuai, \& L. Yang, 2010. Effect of climate, hydrological and ecological processes on Yanghe Reservoir's eutrophication. Journal of Hydroecology (in Chinese) 3(3): 28-31.

Grime, J. P., 1988. The CSR model of primary plant strategiesorigins, implications and tests. In Gottlib, L. D. \& K. S. Jain (eds), Plant Evolutionary Biology. Springer, Berlin: 371-393.

Kingsolver, J. G., \& R. B. Huey, 2008. Size, temperature, and fitness: three rules. Evolutionary Ecology Research 10(2): 251-268.

Kirk, J. T. O., 2011. Light and Photosynthesis in Aquatic Ecosystems. Cambridge University Press, Cambridge.

Komárek, J., \& K. Anagnostidis, 1998. Cyanoprokaryota 1, Vol. 19(1). DEU. Gustav Fischer Verlag Jena, Stuttgart.

Komárek, J., \& B. Fott, 1983. Das Phytoplankton des Susswassers 7 volume 16. E. Schweizerbart.sche Verlagsbuchhandlung, Stuttgart.

Kruk, C., V. L. M. Huszar, E. T. H. M. Peeters, S. Bonilla, L. Costa, M. Lürling, C. S. Reynolds, \& M. Scheffer, 2010. A morphological classification capturing functional variation in phytoplankton. Freshwater Biology 55(3): 614-627.

Lewis, W. M., 1976. Surface/volume ratio: implications for phytoplankton morphology. Science 192(4242): 885-887.

Li, Z., J. Yu, M. Yang, J. Zhang, M. D. Burch, \& W. Han, 2010. Cyanobacterial population and harmful metabolites dynamics during a bloom in Yanghe Reservoir, North China. Harmful Algae 9(5): 481-488.

Ling, H. U., \& A. T. Peter, 2000. Australian Freshwater Algae (exclusive of diatoms), Vol. 5. J. Cramer in der Gebrueder Borntraeger Verlagsbuchhandlung Antarctic Division, Channel Highway, Kingston.

Litchman, E., P. de Tezanos Pinto, C. A. Klausmeier, M. K. Thomas \& K. Yoshiyama, 2010. Linking traits to species diversity and community structure in phytoplankton. Hydrobiologia 653(1): 15-28.

Margalef, R., 1978. Life-forms of phytoplankton as survival alternatives in an unstable environment. Oceanologica Acta 1(4): 493-509.

Naselli-Flores, L., 2000. Phytoplankton assemblages in twentyone Sicilian reservoirs: relationships between species composition and environmental factors. Hydrobiologia 424:1-11.

Naselli-Flores, L., \& R. Barone, 2003. Steady-state assemblages in a Mediterranean hypertrophic reservoir. The role of Microcystis ecomorphological variability in maintaining an apparent equilibrium. Hydrobiologia 502: 133-143.

Naselli-Flores, L., \& R. Barone, 2005. Water-level fluctuations in Mediterranean reservoirs: setting a dewatering threshold as a management tool to improve water quality. Hydrobiologia 548(1): 85-99.

Naselli-Flores, L., \& R. Barone, 2007. Pluriannual morphological variability of phytoplankton in a highly productive Mediterranean Reservoir (Lake Arancio, Southwestern Sicily). Hydrobiologia 578: 87-95.

Naselli-Flores, L., \& R. Barone, 2011. Fight on plankton! Or, phytoplankton shape and size as adaptive tools to get ahead in the struggle for life. Cryptogamie Algologie 32(2): 157-204.

Naselli-Flores, L., J. Padisák, \& M. Albay, 2007. Shape and size in phytoplankton ecology: do they matter? Hydrobiologia 578: 157-161.

O'Farrell, I., P. Tezanos Pinto, \& I. Izaguirre, 2007. Phytoplankton morphological response to the underwater light conditions in a vegetated wetland. Hydrobiologia 578: 65-77.

Oliver, R. L., B. T. Hart, J. Olley, M. Grace, C. Rees, \& G. Caitcheon, 1999. The Darling River: algal growth and the cycling and sources of nutrients. CRC for Freshwater Ecology, Canberra.

Örnólfsdóttir, E. B., S. E. Lumsden, \& J. L. Pinckney, 2004. Nutrient pulsing as a regulator of phytoplankton abundance and community composition in Galveston Bay, Texas. Journal of Experimental Marine Biology and Ecology 303(2): 197-220.

Padisák, J., É. Soróczki-Pintér, \& Z. Rezner, 2003. Sinking properties of some phytoplankton shapes and the relation of form resistance to morphological diversity of plankton-an experimental study. Hydrobiologia 500: 243-257.

Padisák, J., L. O. Crossetti, \& L. Naselli-Flores, 2009. Use and misuse in the application of the phytoplankton functional classification: a critical review with updates. Hydrobiologia 621(1): 1-19.

Palmer, J. M., \& B. G. Grant, 2010. The Art of Radiometry. SPIE Press Monograph. SPIE Press, San Francisco.

Prescott, G. W., 1951. Algae of the Western great lakes area: exclusive of desmids and diatoms. Cranbrook Institute of Science, Bloomfield Hills, MI.

Reda, I., \& A. Andreas, 2004. Solar position algorithm for solar radiation applications. Solar Energy 76(5): 577-589.

Reynolds, C. S., 1997. Vegetation Processes in the Pelagic: A Model for Ecosystem Theory. Ecology Institute, Oldendorf.

Reynolds, C. S., 2006. Ecology of Phytoplankton. Cambridge University Press, Cambridge.

Reynolds, C. S., V. Huszar, C. Kruk, L. Naselli-Flores, \& S. Melo, 2002. Towards a functional classification of the freshwater phytoplankton. Journal of Plankton Research 24(5): 417-428.

Smestad, G. P., 1998. Education and solar conversion:: demonstrating electron transfer. Solar Energy Materials and Solar Cells 55(1-2): 157-178.

Taguchi, S., 1976. Relationship between photosynthesis and cell size of marine diatoms. Journal of Phycology 12(2): 185-189.

Talling, J. F., 1965. The photosynthetic activity of phytoplankton in East African lakes. Internationale Revue der gesamten Hydrobiologie und Hydrographie 50(1): 1-32.

Utermöhl, H., 1958. Zur vervollkommnung der quantitativen phytoplankton-methodik. Mitteilungen Internationale 
Vereinigung für Theoretische und Angewandte Limnologie 9: 1-38.

Weithoff, G., 2003. The concepts of 'plant functional types' and 'functional diversity' in lake phytoplankton-a new understanding of phytoplankton ecology? Freshwater Biology 48(9): 1669-1675.
Woolf, H. M., 1968. On the computation of solar elevation angles and the determination of sunrise and sunset times. National Aeronautics and Space Administration, Washington, D.C. 